Economics Development Analysis Journal 6 (2)(2017)

\title{
Analisis Daya Saing Ekspor Sektor Unggulan di Jawa Tengah
}

\section{Wiwit Santi Wahyuningsih ${ }^{\bowtie}$}

Jurusan Ekonomi Pembangunan, Fakultas Ekonomi, Universitas Negeri Semarang.

\begin{tabular}{|c|c|}
\hline Info Artikel & bstrak \\
\hline Sejarah Artikel: & \multirow{6}{*}{$\begin{array}{l}\text { Penelitian ini mengidentifikasi industri unggulan di Jawa Tengah yang mempunyai daya saing } \\
\text { Penelitian ini menggunakan data PDRB Jawa Tengah dan PDB Tahun 2010-2015, Tabel Inpu } \\
\text { Output Jawa Tengah Tahun 2013, serta data Ekspor-Impor Jawa Tengah Tahun 1997-2015 } \\
\text { Penelitian ini mengunakan alat analisis Indeks Daya Penyebaran (IDP), Indeks Derajat Kepekaan } \\
\text { (IDK) dan Revealed Comparative Advantage (RCA). Dari hasil IDP dan IDK terdapat } 9 \text { industri } \\
\text { unggulan di Jawa Tengah yaitu industri pengolahan dan pengawetan ikan, industri minyak dan } \\
\text { lemak, industri penggilingan padi, industri tepung terigu dan tepung lainnya, industri makanan } \\
\text { ternak, industri pemintalan, industri tekstil, industri kayu dan bahan bangunan dari kayu, serta } \\
\text { industri karet dan barang dari karet. Hanya ada } 3 \text { industri yang memiliki daya saing ekspor tingg } \\
\text { yaitu industri dengan IDP }>1 \text {, IDK }>1 \text { dan RCA }>1 \text { yang meliputi industri pemintalan, industri } \\
\text { tekstil, dan industri kayu dan bahan bangunan dari kayu. Dari penelitian ini dapat disimpulkan } \\
\text { bahwa sektor industri yang dapat diandalkan untuk meningkatkan pertumbuhan ekonomi melalu } \\
\text { ekspor dan memiliki daya saing ekspor yang sangat bagus serta memilki harga jual tinggi yaitu hanya } \\
\text { industri pemintalan, industri tekstil, dan industri kayu dan bahan bangunan dari kayu. Maka dar } \\
\text { itu sebaiknya kebijakan pemerintah lebih ditekankan pada sektor hulu dan sektor hilir dari industri- } \\
\text { industri tersebut. }\end{array}$} \\
\hline uari 2017 & \\
\hline 17 & \\
\hline Dipublikasikan Mei 2017 & \\
\hline $\begin{array}{l}\text { Keywords: } \\
\text { Ekspor, Ind }\end{array}$ & \\
\hline & \\
\hline
\end{tabular}

\begin{abstract}
This research identify the leading manufactures in central Java which have the export competitiveness. This study used data of Central Java's Gross Domestic Regional Product (GDRP) and Gross National Product (GNP) on 2010-2015, Input Output Table on 2013, as well as export-import on 1997-2015. This research rely on Forward Linkage Index (FLI), Backward Linkage Index (BLI) and Revealed Comparative Advantage (RCA) analysis tools. There are 9 leading manufacturing industries conducted from the result. Those manufactures are processing and preserving fish industry, oils and fats industry, rice milling industry, wheat flour industry, live and fock feeds industry, knitting industry, textile industry, wood and products of wood industry, and rubber and products of rubber industry. Only 3 industries that have the high export competitiveness. These industries have Forward Linkage Index (FLI) $>1$, Backward Linkage Index (BLI) $>1$, and RCA $>1$ consisting knitting industry, textile industry, and wood and products of wood industry. From this study, it can be concluded that the reliable manufacturing sectors to boot the economy growth through exports, having a good export competitiveness as well as high selling prices are those 3 industries. Therefore the emphasize of goverment policy should be on the upstream and down stream sectors of these industries.
\end{abstract}

(C) 2017 Universitas Negeri Semarang

$\triangle$ Alamat korespondensi: ISSN 2252-6765

Gedung L2 Lantai 2 FE Unnes

Kampus Sekaran, Gunungpati, Semarang, 50229

E-mail: wietsant@gmail.com 


\section{PENDAHULUAN}

Dalam persaingan global, setiap negara dipaksa kreatif dan inovatif agar terjamin keberlangsungan perekonomiannya. Inovasi merupakan syarat penting dalam meningkatkan daya saing internasional (Perlines, et al, 2016). Negaranegara agraris seperti Indonesia harus bekerja keras agar produk utama yang dihasilkan mampu bertahan di kancah perdagangan internasional. Para pembuat kebijakan diharuskan untuk fokus pada daya saing ekspor (Abdullah, et al, 2015).

Salah satu strategi untuk mempercepat peningkatan daya saing adalah dengan proses industrialisasi dimana dengan proses ini mampu mencapai tingkat pendapatan perkapita yang tinggi (Tambunan, 2001). Industrialisasi merupakan suatu proses interaksi antara pengembangan teknologi, inovasi spesialisasi dalam produksi dan perdagangan antar negara yang pada akhirnya sejalan dengan peningkatan pendapatan perkapita dalam mendorong perubahan struktur ekonomi.

Lapangan usaha industri pengolahan mempunyai peranan sebagai sektor pemimpin, maksudnya dengan adanya pembangunan industri maka akan memacu dan mengangkat pembangunan lapangan usaha lainnya seperti lapangan usaha pertanian dan lapangan usaha jasa. Pertumbuhan lapangan usaha industri yang pesat akan merangsang pertumbuhan lapangan usaha pertanian sebagai penyedia bahan baku serta lapangan usaha jasa sebagai penyedia fasilitas pendukung bagi lapangan usaha industri pengolahan. Di sisi lain, mengindikasikan bahwa pertumbuhan ekonomi mulai didominasi oleh lapangan usaha yang lebih banyak berorientasi pada teknologi. Teknologi menjadi konteks penting untuk mempertahankan pertumbuhan ekonomi (Luo, et al, 2014).

Gambar 1. Share Sektor Pertanian, Sektor Industri Pengolahan dan Sektor Lainnya di Jawa Tengah Tahun 1978-2015 (dalam persen)

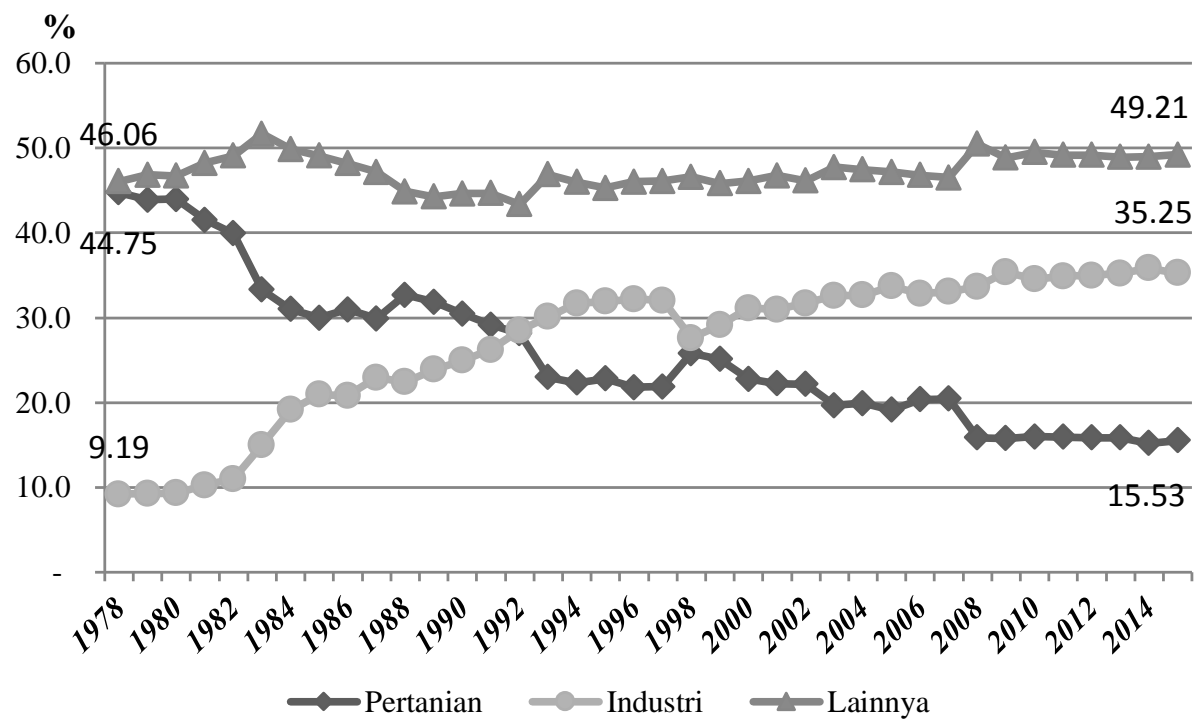

Sumber: PDRB Jawa Tengah, 1978-2015

Potensi lapangan usaha industri pengolahan Jawa Tengah semakin berkembang. Pada era tahun 1970-an lapangan usaha pertanian mendominasi struktur perekonomian Jawa Tengah hingga mencapai 50 persen sedangkan lapangan usaha industri pengolahan hanya berperan 9 persen. Namun pada tahun 2015, terjadi penurunan kontribusi pada komoditi pertanian, terutama padi, sehingga menyebabkan lapangan usaha pertanian hanya berperan 15,5 persen terhadap pembentukan PDRB. Di sisi lain, ekspansi pada hampir semua komoditi industri menyebabkan lapangan usaha industri pengolahan menyumbang 35,3 persen terhadap PDRB Jawa Tengah di tahun 2015. Penurunan kontribusi lapangan usaha pertanian dimulai pada awal tahun 1990-an. Setelah tahun 1993 kontribusi 
lapangan usaha pertanian tidak pernah melebihi lapangan usaha industri pengolahan.

Peningkatan peran lapangan usaha industri pengolahan dalam perekonomian sejalan dengan peningkatan pendapatan per kapita yang terjadi di suatu wilayah, serta berkaitan erat dengan akumulasi kapital dan peningkatan sumber daya manusia (human capital). Berkembangnya aktifitas lapangan usaha industri pengolahan secara tidak langsung turut mendorong peningkatan aktifitas ekspor. Total nilai ekspor Jawa Tengah tahun 2015 mencapai US\$ $5.374,7$ juta. Dimana jika dibandingkan dengan aktifitas ekspor 15 tahun yang lalu (tahun 2000) terjadi peningkatan lebih dari 100 persen. Pada rentang 15 tahun tersebut pertumbuhan nilai ekspor Jawa Tengah cenderung positif.

Menurut pandangan Keynes besarnya tingkat ekspor akan mempengaruhi produksi nasional karena aktivitas ekspor menunjukkan permintaan efektif yang berasal dari luar negeri. Semakin tinggi ekspor artinya semakin tinggi pula produksi lokal yang mampu dipasarkan sehingga akan mendongkrak peningkatan pertumbuhan ekonomi.

Gambar 2. Struktur Perekonomian dan Pertumbuhan Ekonomi Jawa Tengah menurut Pengeluaran Tahun 2008-2015

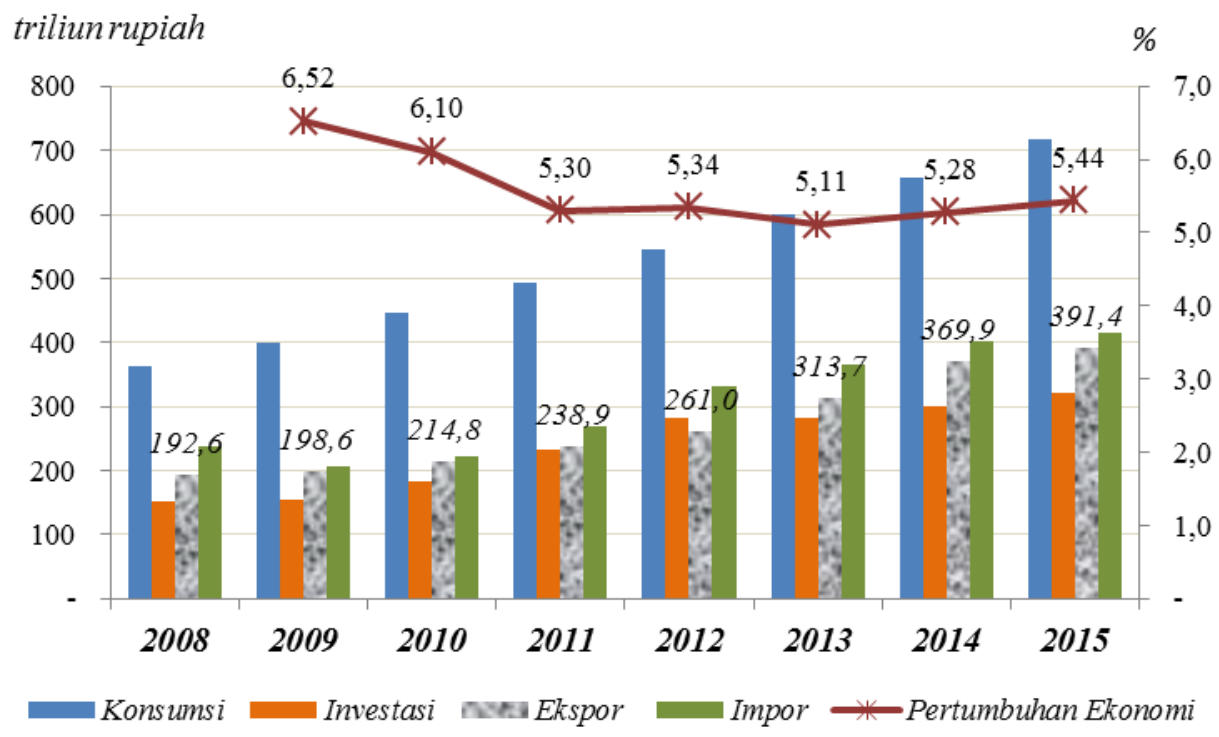

Sumber: PDRB Jawa Tengah, 2008-2015

Gambar 2 memperlihatkan bahwa nilai ekspor Jawa Tengah selalu lebih rendah daripada nilai impornya. Akibatnya terjadi defisit neraca perdagangan di Jawa Tengah. Sehingga dapat dikatakan bahwa Jawa Tengah merupakan daerah importir, dan karena masih terlalu banyak mengimpor daripada mengekspor produk yang dihasilkan maka dapat diartikan daya saing ekspor Jawa Tengah masih rendah. Kondisi ini diduga terkait dengan beberapa faktor yang dapat menghambat perkembangan sektor riil, antara lain rendahnya penyaluran kredit ke sektor riil, teknologi yang relatif sudah jenuh, daya saing yang relatif rendah dan high cost economy (Purnomo dan Devi, 2008).
Peningkatan daya saing internasional memberikan banyak manfaat baik bagi produsen, konsumen maupun perekonomian Jawa Tengah. Kemampuan untuk bersaing akan memberi kesempatan industri untuk menyerap lebih banyak tenaga kerja sehingga mengurangi pengangguran. Laba yang diperoleh juga dapat digunakan untuk menambah investasi serta konsumsi. Singkatnya, akan berdampak pada peningkatan nilai tambah perekonomian Jawa Tengah.

Salah satu aspek yang penting untuk diperhatikan dalam persaingan internasional khususnya untuk daya saing produk ekspor adalah dalam menawarkan sesuatu produk haruslah dengan harga yang sama atau lebih rendah dari harga yang 
ditawarkan oleh pesaing, atau biaya produksinya lebih rendah dari biaya produksi di negara tujuan, sehingga dalam hal ini negara pengekspor memiliki keunggulan komparatif (Amir, 2003).

Lapangan usaha industri memberikan kontribusi terbesar dalam perekonomian Jawa Tengah sehingga dituntut untuk lebih meningkatkan peranannya dalam peningkatan PDRB. Karena kenaikan PDRB dari tahun ke tahun pada dasarnya merupakan gambaran tingkat pertumbuhan ekonomi yang dicapai suatu daerah. Dalam rangka meningkatkan pertumbuhan ekonomi yang lebih tinggi maka perlu untuk memprioritaskan kebijakan ke lapangan usaha industri yang menjadi unggulan, yaitu yang memiliki kemampuan mempengaruhi lapangan usaha lainnya untuk tumbuh seiring dengan pertumbuhannya sendiri. Kemampuan tersebut akan muncul apabila ada dorongan pasar yang tinggi, terutama pasar ekspor. Oleh karena itu perlu diadakan suatu penelitian untuk mengidentifikasi lapangan usaha industri yang menjadi unggulan serta komoditi yang dihasilkannya yang memiliki daya saing ekspor tinggi.

Penelitian ini akan mengidentifikasi dan menganalisis industri unggulan serta komoditi yang dihasilkannya yang mempunyai daya saing ekspor tinggi dalam perekonomian Jawa Tengah. Serta memberikan saran kebijakan yang nantinya dapat digunakan untuk meningkatkan produktifitas industri bersangkutan.

Menurut Tarigan (2007) bahwa laju pertumbuhan ekonomi suatu wilayah ditentukan oleh besarnya peningkatan ekspor dari wilayah tersebut. Begitu pula dengan pendapat para penganut Merkantilisme yang menyatakan bahwa satu-satunya cara bagi sebuah negara untuk menjadi kaya dan kuat adalah dengan melakukan sebanyak mungkin ekspor dan sesedikit mungkin impor. Surplus ekspor yang dihasilkan selanjutnya dibentuk dalam aliran emas lantakan atau logam-logam mulia khususnya emas dan perak. Sehingga semakin banyak emas dan perak yang dimiliki, maka semakin kaya dan kuatlah negara tersebut. Dengan demikian, pemerintah harus menggunakan seluruh kekuatannya untuk mendorong ekspor dan mengurangi serta membatasi impor (Salvatore, 1997).

Dalam perdagangan bebas antar daerah, mekanisme pasar mendorong masing-masing daerah bergerak ke arah sektor yang memiliki keunggulan komparatif. Namun mekanisme pasar seringkali bergerak lambat dalam mengubah struktur ekonomi suatu daerah. Untuk itu informasi tentang keunggulan komparatif suatu daerah apabila sudah diketahui lebih dulu, pembangunan dapat dilakukan tanpa menunggu mekanisme pasar (Tarigan, 2006).

Hukum keunggulan komparatif menyatakan bahwa meskipun sebuah negara kurang efisien dibanding (atau memiliki kerugian absolut terhadap) negara lain dalam memproduksi 2 (dua) jenis komoditi, namun masih tetap terdapat dasar untuk melakukan perdagangan yang menguntungkan kedua belah pihak. Negara tersebut harus melakukan spesialisasi dalam memproduksi dan mengekspor barang yang memiliki kerugian absolut lebih kecil (ini merupakan komoditi dengan keunggulan komparatif) dan mengimpor komoditi yang memiliki kerugian absolut lebih besar (komoditi ini memiliki kerugian komparatif).

\section{METODE PENELITIAN}

Data yang digunakan dalam penelitian ini berupa data sekunder, yaitu menggunakan data yang ada pada Tabel I-O Jawa Tengah Tahun 2013 (85 x 85 sektor), Data PDB dan PDRB Jawa Tengah Tahun 2008-2015, serta data ekspor Indonesia dan Jawa Tengah Tahun 2010-2015, yang diperoleh dari Badan Pusat Statistik Provinsi Jawa Tengah.

Dalam penelitian ini akan menggunakan 2 (dua) alat analisis, yaitu Indeks Daya Penyebaran (IDP) dan Indeks Derajat Kepekaan (IDK) yang terdapat pada Tabel Input Output untuk menentukan sektor unggulan dan Revealed Comparative Advantage (RCA) untuk mengidentifikasi sektor-sektor ekonomi serta komoditi-komoditinya yang mempunyai daya saing ekspor tinggi.

Sudah banyak ahli yang menggunakan IDP dan IDK untuk menganalisa dan menentukan sektorsektor kunci (key sectors) yang akan dikembangkan dalam pembangunan ekonomi di suatu wilayah. Sektor yang mempunyai IDP tinggi memberikan indikasi bahwa sektor tersebut mempunyai keterkaitan ke depan atau daya dorong yang cukup kuat dibandingkan terhadap sektor lainnya. Sebaliknya sektor yang mempunyai IDK tinggi berarti 
sektor tersebut mempunyai ketergantungan (kepekaan) yang tinggi terhadap sektor lain.

Adapun sektor-sektor yang mempunyai IDP yang lebih besar dari 1 , berarti daya penyebaran sektor tersebut di atas rata-rata daya penyebaran secara keseluruhan. Pengertian yang sama juga berlaku untuk IDK. Sektor yang mempunyai IDK lebih dari satu, berarti derajat kepekaan sektor tersebut di atas derajat kepekaan rata-rata secara keseluruhan.

Metode Revealed Coparatif Advantage (RCA) merupakan metode untuk mengetahui komoditi apa yang mempunyai keunggulan atau yang memiliki prestasi ekspor di suatu daerah/wilayah. RCA dapat dihitung dengan cara sebagai berikut:

$$
R C A=\frac{X L_{i} / X L_{w}}{X_{i} / X_{w}}
$$

dimana,

$$
\begin{array}{ll}
\mathrm{XLi} & =\text { nilai ekspor komoditi } \mathrm{L} \text { Jawa Tengah } \\
\mathrm{XLw} & =\text { nilai ekspor komoditi } \mathrm{L} \text { Indonesia } \\
\mathrm{Xi} & =\text { total nilai ekspor Jawa Tengah } \\
\mathrm{Xw} & =\text { total nilai ekspor Indonesia }
\end{array}
$$

Ketentuan dari RCA adalah nilai 1 merupakan garis pemisah antara keunggulan dan ketidakunggulan komparatif. Jadi jika nilai indeks RCA lebih besar dari 1 memperlihatkan daya saing produk tertentu cukup kuat terhadap produk lainnya di suatu wilayah yang diukur secara rata-rata. Sedangkan indeks RCA lebih kecil dari 1 memperlihatkan tidak adanya daya saing produk tertentu di wilayah tersebut.
Dengan perhitungan ini dapat diketahui keunggulan komparatif komoditi unggulan di Jawa Tengah. Nilai RCA $>1$ menunjukkan bahwa pangsa komoditi unggulan dalam ekspor total Jawa Tengah lebih besar dari pangsa rata-rata dari komoditi yang bersangkutan dalam ekspor Indonesia, artinya bahwa Jawa Tengah relatif lebih berspesialisasi pada komoditi yang bersangkutan.

\section{HASIL DAN PEMBAHASAN}

Lapangan usaha industri pengolahan sangat berperan penting dalam perekonomian Jawa Tengah.Terbukti dari kontribusi lapangan usaha ini yang memberikan nilai tambah terbesar di antara lapangan usaha lainnya. Berdasarkan angka Produk Domestik Regional Bruto (PDRB), pada tahun 2013 kontribusi lapangan usaha industri pengolahan terhadap perekonomian Jawa Tengah mencapai 35,21 persen, kemudian meningkat menjadi 35,84 persen di tahun 2014 dan pada tahun 2015 mencapai 35,25 persen (Tabel 1). Kontribusi tersebut cenderung mengalami kenaikan setiap tahunnya.

Pertumbuhan lapangan usaha industri pengolahan dari tahun 2010 sampai tahun 2015 selalu positif untuk setiap tahunnya. Kondisi ini tidak terlepas dari menguatnya kinerja sejumlah industri yang selama ini memberi kontribusi besar bagi perekonomian Jawa Tengah sehingga rata-rata perkembangan dan pertumbuhan industri secara umum meningkat.

Tabel 1. Pertumbuhan Lapangan Usaha Industri Pengolahan dan Kontribusinya Terhadap PDRB Jawa Tengah, Tahun 2010-2015 (persen)

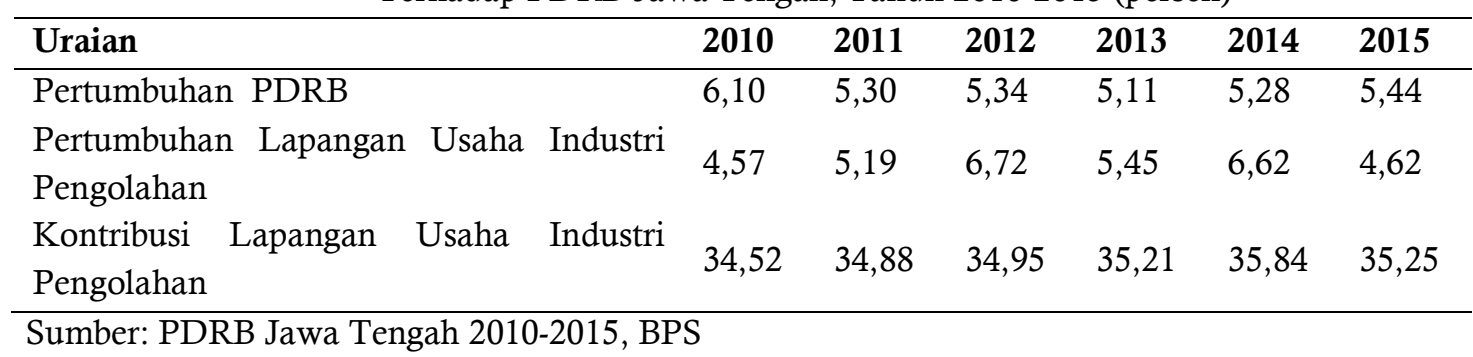

Pada Tabel 2 tampak bahwa pada tahun 2015, lapangan usaha industri pengolahan berada pada urutan pertama yang memberikan kontribusi terbesar terhadap perekonomian Jawa Tengah sebesar Rp 357.508,7 miliar (35,25 persen), kemudian diikuti lapangan usaha pertanian, kehutanan dan perikanan sebesar Rp 157.498,1 miliar (15,53 persen) dan lapangan usaha perdagangan besar dan eceran, reparasi mobil dan sepeda motorsebesar Rp 135.032,8 miliar (13,32 persen). Sejak 20 tahun terakhir 
kontribusi lapangan usaha industri pengolahan menjadi the leading sector terhadap perekonomian Jawa Tengah.

Upaya perbaikan yang dibutuhkan antara lain adalah efisiensi produksi. Permasalahan ekonomi biaya tinggi yang bersumber dari birokrasi baik yang menyangkut proses perizinan maupun pemasaran produk, stabilitas keamanan, kondisi infrastruktur dan kepastian hukum, masih merupakan kendala bagi dunia investasi di Jawa Tengah. Selain itu, maraknya arus masuk barang-barang impor dampak dari globalisasi perdagangan bebas membuat produk buatan industri lokal sulit bersaing.

Tabel 2. PDRB Menurut Lapangan Usaha Utama di Jawa Tengah,

Tahun 2010-2015 (Miliar Rupiah)

\begin{tabular}{lllllll}
\hline Lapangan Usaha & $\mathbf{2 0 1 0}$ & $\mathbf{2 0 1 1}$ & $\mathbf{2 0 1 2}$ & $\mathbf{2 0 1 3}$ & $\mathbf{2 0 1 4}$ & $\mathbf{2 0 1 5}$ \\
\hline Pertanian & $99.572,4$ & $110.425,4$ & $119.706,9$ & $131.450,7$ & $140.621,9$ & $157.498,1$ \\
Industri Pengolahan & $215.156,5$ & $241.531,8$ & $263.739,8$ & $292.260,7$ & $331.604,5$ & $357.508,7$ \\
Perdagangan & $91.678,7$ & $103.050,8$ & $107.278,0$ & $115.983,9$ & $124.861,7$ & $135.032,8$ \\
Lainnya & $216.817,0$ & $237.553,6$ & $263.804,8$ & $290.320,7$ & $328.106,6$ & $364.034,6$ \\
Total PDRB & $623.224,6$ & $692.561,6$ & $754.529,4$ & $830.016,0$ & $925.194,7$ & $1.014 .074,2$ \\
\hline
\end{tabular}

Sumber: PDRB Jawa Tengah 2010-2015, BPS

Seiring dengan perkembangan globalisasi, kegiatan ekspor menjadi semakin penting karena merupakan salah satu penggerak perekonomian suatu wilayah. Era globalisasi dan perdagangan bebas telah mendorong persaingan antar wilayah menjadi semakin ketat. Setiap wilayah, termasuk Jawa Tengah, berusaha terus meningkatkan kuantitas dan kualitas ekspornya. Semua wilayah terus meningkatkan daya saing produknya agar lebih efisien dan laku di pasar internasional.
Selama tahun 2007 sampai 2015 perkembangan nilai ekspor dan impor Jawa Tengah cenderung berfluktuasi. Gambar 3 memperlihatkan perkembangan ekspor dan impor di Jawa Tengah, dimana pada tahun 2007 nilai ekspor Jawa Tengah mencapai US $\$ 3,5$ juta, selanjutnya pada tahun 2008 dan 2009 mengalami sedikit penurunan hingga hanya mencapai US $\$ 3,1$ juta, namun kembali mengalami peningkatan dan pada tahun 2015 mampu mencapai US\$5, 4 juta.

Gambar 3. Nilai Ekspor dan Impor Jawa Tengah, Tahun 2007-2015

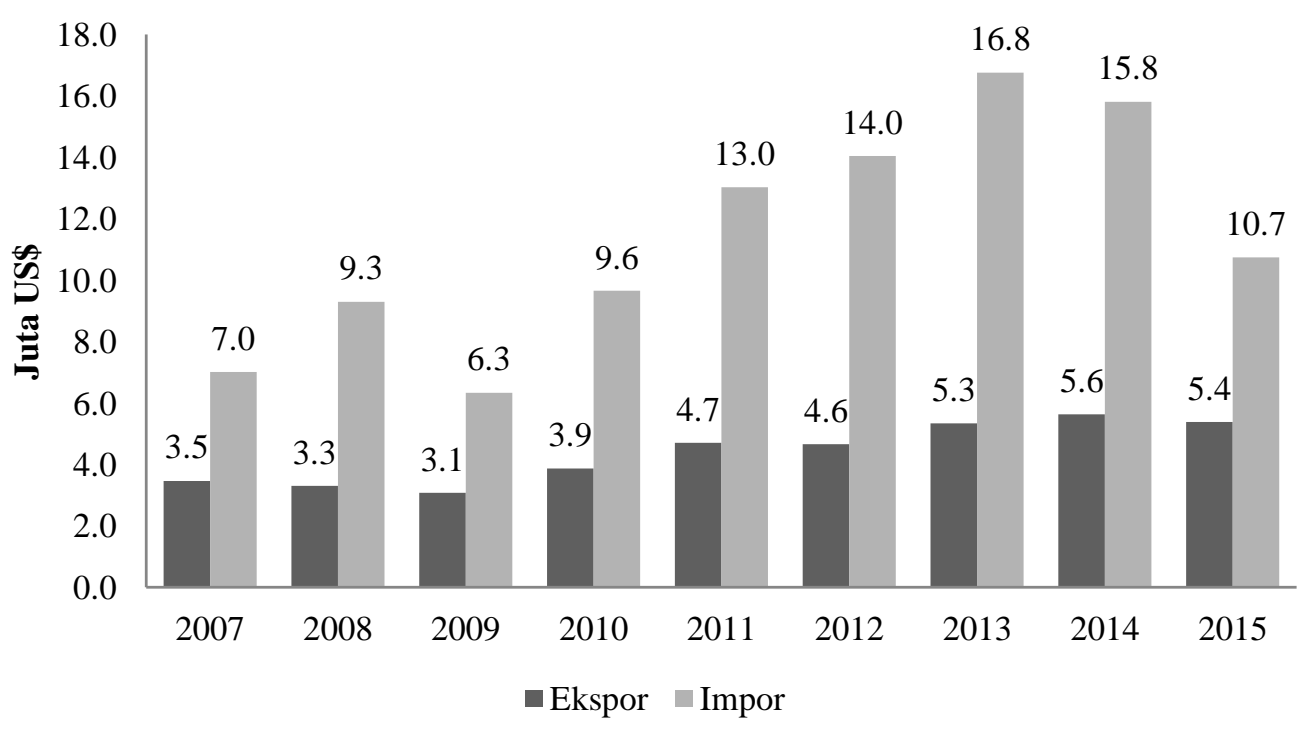

Sumber: Statistik Ekspor-Impor, Tahun 2007-2015 
Meskipun Jawa Tengah dikenal sebagai wilayah berbasis pertanian, namun sebagian besar komoditi ekspor Jawa Tengah merupakan produk hasil industri. Produk pertanian yang mampu menembus pasar internasional tidak pernah mampu mencapai 10 persen dari total nilai ekspor Jawa Tengah. Produk ekspor non migas Jawa Tengah sebagian besar terdiri atas barang tekstil dan barang- barang dari kayu. Dimana setiap tahunnya nilai ekspor barang tekstil mencapai kisaran 40 persen dan nilai ekspor barang-barang dari kayu mencapai kisaran 17 persen dari total nilai ekspor Jawa Tengah. Negara tujuan utama ekspor Jawa Tengah adalah Amerika Serikat, Jepang dan Cina. Sepuluh besar komoditi ekspor Jawa Tengah dapat dilihat pada Tabel 3.

Tabel 3. Sepuluh Besar Komoditi Ekspor Jawa Tengah, Tahun 2010-2015 (Juta US\$)

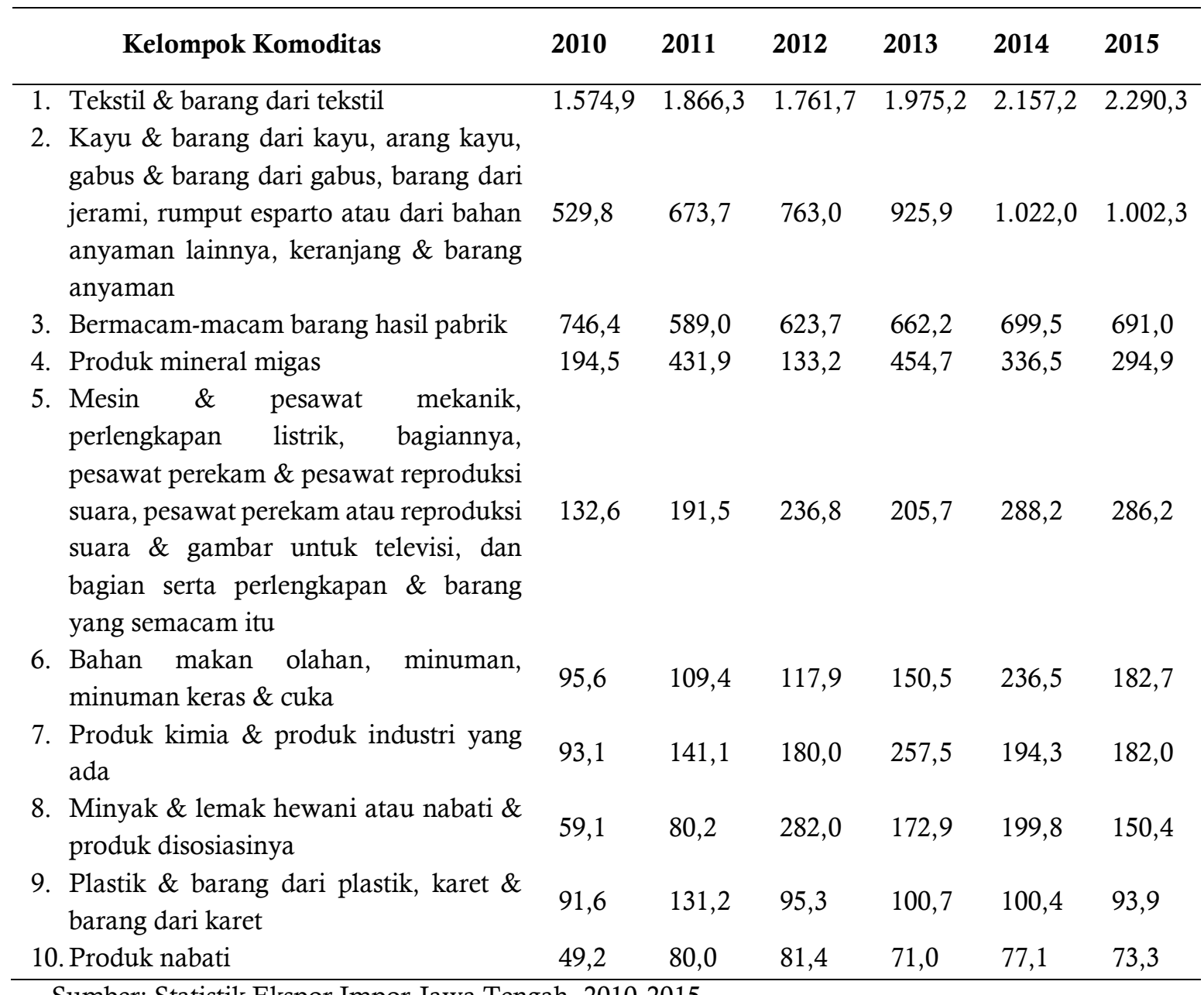

Sumber: Statistik Ekspor Impor Jawa Tengah, 2010-2015

Dalam Tabel 4 menyajikan 24 sektor yang memiliki nilai IDP lebih besar dari satu (IDP>1) berdasarkan Tabel Input Output Jawa Tengah Tahun 2013.

Dari hasil olahan data Tabel Input Output Jawa Tengah Tahun 2013, Industri Penggilingan Padi memiliki nilai IDP paling besar yaitu mencapai 1,41457. Hal ini menunjukkan bahwa kenaikan 1 unit output sektor industri penggilingan padi akan menyebabkan naiknya output sektor-sektor lain (termasuk sektor industri penggilingan padi) secara keseluruhan sebesar 1,41457 unit.Sepuluh sektor industri yang memiliki IDP terbesar berikutnya adalah Sektor Industri Roti dan Kue Kering Lainnya $(1,41028)$, disusul Sektor Industri Bumbu Masak dan Penyedap Masakan (1,38819), Sektor Pakaian Jadi (1,33939), Sektor Makanan Lainnya (1,33311), Industri Kulit dan Alas Kaki (1,32313), Sektor 
Industri Perabot Rumahtangga dari Kayu $(1,30406)$, Sektor Industri Makanan Ternak (1,26775), Sektor Industri Minyak dan Lemak (1,26036), Sektor Industri Kopi Giling dan Kupasan $(1,25202)$, dan Sektor Industri Farmasi dan Jamu Tradisional $(1,25173)$.
Output yang dihasilkan oleh sektor tersebut merupakan komoditi intermedier, dalam artian merupakan bahan baku bagi industri maupun sektor perekonomian lainnya.

Tabel 4. Sektor Dengan IDP>1 Menurut Tabel Input Output Jawa Tengah Tahun 2013

\begin{tabular}{llr}
\hline No & \multicolumn{1}{c}{ Nama Sektor } & IDP \\
\hline 1 & Industri Penggilingan Padi & 1,41456 \\
2 & Industri Roti dan Kue Kering Lainnya & 1,41028 \\
3 & Industri Bumbu Masak dan Penyedap Masakan & 1,38819 \\
4 & Industri Pakaian Jadi & 1,33939 \\
5 & Industri Makanan Lainnya & 1,33311 \\
6 & Industri Kulit dan Alas Kaki & 1,32313 \\
7 & Industri Perabot Rumahtangga dari kayu & 1,30406 \\
8 & Industri Makanan Ternak & 1,26775 \\
9 & Industri Minyak dan Lemak & 1,26036 \\
10 & Industri Kopi Giling dan Kupasan & 1,25202 \\
11 & Industri Farmasi dan Jamu Tradisonal & 1,25173 \\
12 & Industri Minuman & 1,24717 \\
13 & Industri Tepung Terigu dan Tepung Lainnya & 1,23839 \\
14 & Industri Kayu dan Bahan Bangunan dari Kayu & 1,22725 \\
15 & Industri Tekstil Jadi dan Tekstil Lainnya & 1,22115 \\
16 & Industri Pengolahan dan Pengawetan Makanan & 1,21830 \\
17 & Indusri Pemintalan & 1,19963 \\
18 & Industri Tekstil & 1,16784 \\
19 & Industri Barang Lainnya & 1,16568 \\
20 & Industri barang Mineral Bukan logam & 1,10464 \\
21 & Industri Kertas dan Barang dari Kertas & 1,09464 \\
22 & Industri Pengolahan Tembakau selain Rokok & 1,07386 \\
23 & Industri Karet dan Barang dari Karet & 1,04701 \\
24 & Penerbitan dan Percetakan & 1,04006 \\
\hline
\end{tabular}

Sumber: Tabel Input Output Jawa Tengah Tahun 2013, diolah

Indeks total keterkaitan ke belakang (backward linkage) atau yang biasa disebut Indeks Derajat Kepekaan (IDK) yang memiliki nilai lebih besar dari satu menunjukkan bahwa sektor tersebut mempunyai kemampuan yang kuat untuk menarik pertumbuhan output sektor hulunya. Nilai indeks lebih besar dari satu menunjukkan derajat kepekaan di sektor industri berada di atas rata-rata derajat kepekaan seluruh sektor perekonomian di Jawa Tengah. Dari hasil olah data Tabel Input Output Jawa Tengah Tahun 2013 maka dapat diperoleh 12 sektor industri yang mempunyai IDK lebih besar dari satu (IDK >1) seperti yang disajikan dalam Tabel 5.

Sektor Industri Pengilangan Minyak merupakan sektor yang memiliki nilai Indeks Derajat Kepekaan yang paling tinggi yaitu sebesar 3,97704, artinya apabila terjadi kenaikan permintaan akhir atas sektor-sektor lain sebesar 1 unit maka sektor industri pengilangan minyak akan mengalami peningkatan output sebesar 3,97704 unit. 
Tabel 5. Sektor dengan IDK>1 Menurut Tabel Input Output Jawa Tengah Tahun 2013

\begin{tabular}{llc}
\hline No & \multicolumn{1}{c}{ Nama Sektor } & IDK \\
\hline 1 & Industri Pengilangan Minyak & 3,97704 \\
2 & Industri Kimia dan Pupuk & 1,53166 \\
3 & Industri Kayu dan Bahan Bangunan dari Kayu & 1,35248 \\
4 & Industri Minyak dan Lemak & 1,25439 \\
5 & Industri Tekstil & 1,22832 \\
6 & Industri Penggilingan Padi & 1,19708 \\
7 & Industri Makanan Ternak & 1,12834 \\
8 & Industri Tepung Terigu dan Tepung Lainnya & 1,12313 \\
9 & Industri Gula Tebu dan Gula Kelapa & 1,07374 \\
10 & Industri Pemintalan & 1,07368 \\
11 & Industri Karet dan Barang dari Karet & 1,04646 \\
12 & Industri Pengolahan dan Pengawetan Makanan & 1,00204 \\
\hline
\end{tabular}

Sumber: Tabel Input Output Jawa Tengah Tahun 2013, diolah

Sektor industri yang memiliki IDK $>1$ berikutnya adalah Industri Kimia dan Pupuk (1,53166), Industri Kayu dan Bahan Bangunan dari Kayu (1,35248), Industri Minyak dan Lemak (1,25439), Industri Tekstil (1,22832), Industri Penggilingan Padi (1,19708), Industri Makanan Ternak (1,12834), Industri Tepung Terigu dan Tepung Lainnya (1,12313), Industri Gula Tebu dan Gula Kelapa (1,07374), Industri Pemintalan (1,07368), Industri Karet dan Barang dari Karet $(1,04646)$, dan Industri Pengolahan dan Pengawetan Makanan (1,00204). Industri-industri ini bisa dikatakan merupakan industri yang kepekaan tinggi karena sangat cepat dalam merespon perubahan output sektor-sektor lain yang berkaitan dengan sektornya. Atau dengan kata lain industri dengan IDK $>1$ kemampuan tumbuhnya tergantung dengan pertumbuhan sektor-sektor yang lain.

Berdasarkan indeks daya penyebaran (IDP) dan indeks derajat kepekaan (IDK), sektor-sektor industri di Jawa Tengah dapat dikelompokkan ke dalam empat kuadran, sebagai berikut:

- Kuadran I (IDP>1 dan IDK>1) meliputi 9 sektor industri, yaitu industri pengolahan dan pengawetan ikan, industri minyak dan lemak, industri penggilingan padi, industri tepung terigu dan tepung lainnya, industri makanan ternak, industri pemintalan, industri tekstil, industri kayu dan bahan bangunan dari kayu, serta industri karet dan barang dari karet;

- Kuadran II (IDP $<1$ dan IDK $>1$ ), yang meliputi 3 sektor industri yaitu industri gula tebu dan gula kelapa, industri kimia dan pupuk serta industri pengilangan minyak;

- Kuadran III (IDP $<1$ dan IDK $<1)$, yang meliputi 8 sektor industri yaitu industri rokok, industri plastik dan barang dari plastik, industri semen, industri kapur dan barang dari semen, industri logam dasar baja dan besi, industri logam bukan besi dan barang dari logam, industri mesin-mesin dan perlengkapan listrik, serta industri alat angkutan dan perbaikannya;

- Kuadran IV (IDP>1 dan IDK<1), yang meliputi 15 sektor indri, yaitu industri roti dan kue kering lainnya, industri kopi giling dan kupasn, industri makanan lainnya, industri bumbu masak dan penyedap masakan, industri minuman, industri pengolahan tembakau selain rokok, industri tekstil jadi dan tekstil lainnya, industri pakaian jadi, industri kulit dan alas kaki, industri perabot 
rumahtangga dari kayu, industri kertas dan barang dari kertas, penerbitan dan percetakan, industri farmasi dan jamu tradisional, industri barang mineral bukan logam, serta industri barang lainnya.

Untuk memberikan gambaran yang lebih jelas mengenai pembagian serta posisi masing-masing sektor industri, secara lengkap dapat dilihat pada Gambar 4 dibawah ini.

Sehingga dapat dikatakan bahwa menurut scatter plot hasil penghitungan IDP dan IDK dapat dinyatakan bahwa yang merupakan sektor unggulan adalah kelompok industri yang berada pada kuadran I, yaitu yang memiliki IDP $>1$ dan IDK $>1$.

Dengan penghitungan tingkat daya saing memperlihatkan bahwa tidak semua sektor industri di
Jawa Tengah memiliki daya saing. Hal ini terlihat dari hasil penghitungan bahwa sebagian besar sektor industri di Jawa Tengah mempunyai nilai RCA kurang dari $1(\mathrm{RCA}<1)$. Tabel 4.7 menunjukkan 11 sektor industri yang dalam enam tahun terakhir mempunyai nilai RCA lebih besar dari 1. Berturutturut sektor industri yang yang mempunyai RCA $>1$ diurutkan dari yang terbesar adalah industri bumbu masak dan penyedap masakan, industri gula tebu dan gula kelapa, industri rokok, industri pemintalan, industri tekstil, industri tekstil jadi dan tekstil lainnya, industri pakaian jadi, industri kayu dan bahan bangunan dari kayu, industri perabot rumahtangga dari kayu, penerbitan dan percetakan, serta industri kapur dan barang dari semen.

Gambar 4. Scatter Plot Hasil Penghitungan IDP dan IDK Berdasarkan Tabel Input Output Jawa Tengah Tahun 2013

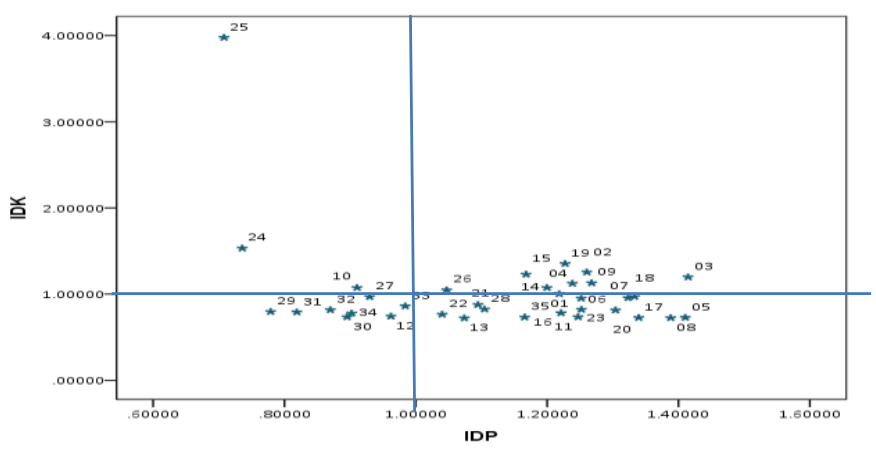

Dari 11 sektor industri yang mempunyai daya impor. Industri tersebut adalah industri pemintalan saing ekspor tinggi, ternyata terdapat dua sektor dan industri tekstil. industri yang bahan baku produksinya tergantung dari

Tabel 6. Sektor Yang Mempunyai Daya Saing Ekspor Tinggi (RCA $>1)$ Selama 6 Tahun Terakhir di Jawa Tengah, Tahun 2010-2015

\begin{tabular}{lcccccc}
\hline \multirow{2}{*}{\multicolumn{1}{c}{ Sektor }} & \multicolumn{5}{c}{ Nilai RCA } \\
\cline { 2 - 7 } & $\mathbf{2 0 1 0}$ & $\mathbf{2 0 1 1}$ & $\mathbf{2 0 1 2}$ & $\mathbf{2 0 1 3}$ & $\mathbf{2 0 1 4}$ & $\mathbf{2 0 1 5}$ \\
\hline Ind. Bumbu Masak \& Penyedap Rasa & 16,9853 & 14,9559 & 9,5340 & 8,3159 & 6,7721 & 3,7980 \\
Ind. Gula Tebu \& Gula Kelapa & 2,7097 & 1,9349 & 1,5998 & 2,6260 & 3,6591 & 2,9907 \\
Industri Rokok & 3,1728 & 3,0991 & 3,5704 & 2,7665 & 2,2430 & 2,0447 \\
Industri Pemintalan & 6,6717 & 7,0433 & 6,4427 & 6,6474 & 6,0635 & 6,0749 \\
Industri Tekstil & 7,3824 & 7,2697 & 4,2947 & 6,2223 & 3,4351 & 2,9987 \\
Industri Tekstil Jadi \& Tekstil Lainnya & 6,9508 & 9,1796 & 12,7991 & 7,6925 & 7,9026 & 6,1225 \\
Industri Pakaian Jadi \& Tekstil Lainnya & 5,6119 & 6,0743 & 6,0850 & 6,0415 & 5,6814 & 5,8428 \\
Industri Kayu \& Bahan Bangunan dari Kayu & 6,0744 & 7,3776 & 7,6450 & 6,4291 & 6,8694 & 5,9666 \\
Industri Perabot Rumahtangga dari Kayu & 11,3705 & 8,1410 & 9,1318 & 9,6631 & 8,6883 & 8,2404 \\
Penerbitan \& Percetakan & 2,5111 & 3,1569 & 2,9745 & 1,8719 & 3,9332 & 5,1448 \\
Ind. Kapur dan Barang dari Semen & & 2,3324 & 2,4925 & 2,1082 & 2,1719 & 1,6532 \\
& 1,9784 & & & & & \\
\hline
\end{tabular}

Sumber: Data Ekspor Jawa Tengah dan Indonesia, diolah 
Namun realitanya industri yang tergantung dari impor sangat rentan terhadap goncangan ekonomi. Naik turunnya nilai kurs serta stabilitas ekonomi global sangat mempengaruhi kinerja produksi industri bersangkutan.Meskipun begitu komoditi yang dihasilkan ketiga sektor industri tersebut merupakan produk ekspor andalan Jawa Tengah.

Sektor unggulan dikatakan mempunyai daya saing ekspor tinggi jika memiliki nilai IDP $>1$, IDK $>1$ dan RCA $>1$. Pengelompokan industri berdasarkan IDP, IDK dan RCA yang lebih rinci akan terlihat jika diamati pada satu titik, misalnya pada tahun 2010 dan 2015. Masing-masing tahun akan terdiri dari 8 kuadran dengan kriteria tertentu sehingga bisa diperbandingkan dan dapat dilihat polanya. Pada Tabel 7 terlihat bahwa antara tahun 2010 dan 2015 tidak menunjukkan perubahan yang berarti pada tingkat daya saing masing-masing sektor.

Tabel 7. Perbandingan Posisi Sektor Berdasarkan IDP, IDK dan RCA Tahun 2010 dan 2015

\begin{tabular}{lll}
\hline \multirow{2}{*}{ Kriteria } & \multicolumn{1}{c}{ Sektor } \\
\cline { 2 - 3 } & \multicolumn{1}{c}{ Tahun 2010 } & \multicolumn{1}{c}{ Tahun 2015 } \\
\hline IDP $>1$, IDK $>1$, RCA $>1$ & $45,46,50$ & $32,45,46,50$ \\
IDP $>1$, IDK $>1$, RCA $<1$ & $32,33,34,35,40,57$ & $33,34,35,40,57$ \\
IDP $<1$, IDK $>1$, RCA $>1$ & 41 & 41 \\
IDP $<1$, IDK $>1$, RCA $<1$ & 55,56 & 55,56 \\
IDP $<1$, IDK $<1$, RCA $<1$ & $58,62,63,64,65$ & $58,62,63,64,65,66$ \\
IDP $<1$, IDK $<1$, RCA $>1$ & $43,61,66$ & 43,61 \\
IDP $>1$, IDK $<1$, RCA $<1$ & $37,38,42,44,49,52,54,59$, & $36,37,38,42,44,49,52,54$, \\
IDP $>1$, IDK $<1$, RCA $>1$ & 66 & 59,66 \\
\hline
\end{tabular}

Sumber: Lampiran 2 dan 3

Pada tahun 2010, industri yang menjadi sektor unggulan yang berdaya saing ekspor, yaitu dengan kriteria IDP $>1$, IDK $>1$ dan RCA $>1$ adalah industri pemintalan, industri tekstil, dan industri kayu dan bahan bangunan dari kayu. Sedangkan pada tahun 2015 pada kriteria yang sama selain ketiga sektor industri yang ada di tahun 2010 ditambah dengan industri pengolahan dan pengawetan makanan. Padahal sektor industri pengolahan dan pengawetan makanan ketika tahun 2010 meskipun merupakan sektor industri unggulan tapi memiliki daya saing ekspor rendah. Hal ini mengindikasikan bahwa terjadi perubaan positif pada industri tersebut untuk berperan lebih di pasar internasional sehingga mampu mendatangkan tambahan pendapatan bagi Jawa Tengah.
Berdasarkan hasil pengolahan data menggunakan IDP, IDK dan RCA ditemukan bahwa dalam rentang waktu 2010-2015 terdapat 26 jenis komoditi ekspor dari sektor industri unggulan yang mempunyai daya saing ekspor tinggi karena secara konsisten memiliki RCA $>1$.

Pada industri pemintalan terdapat 9 komoditi ekspor yang secara konsisten mempunyai daya saing ekspor tinggi, yaitu noil dari wol atau dari bulu hewan halus; benang kapas (selain benang jahit) yang mengandung kapas 85 persen; benang filament sintetik (selain benang jahit); benang (selain benang jahit) dari serat staple sintetik danbenang (selain benang jahit) dari serat staple artifisial. Dimana dari jenis-jenis komoditi tersebut terdiri dari berbagai ukuran. 
Tabel 8. Komoditi Ekspor yang Berdaya Saing Tinggi Tahun 2010-2015

\begin{tabular}{|c|c|c|c|c|c|c|}
\hline \multirow{2}{*}{$\begin{array}{c}\text { Kode } \\
\text { Komoditi } \\
14\end{array}$} & \multicolumn{6}{|c|}{ Nilai RCA } \\
\hline & 2010 & 2011 & 2012 & 2013 & 2014 & 2015 \\
\hline 5103100000 & 5.4311 & 5.4374 & 5.5382 & 10.8641 & 4.4697 & 3.8938 \\
\hline 5205210000 & 1.3904 & 2.9458 & 2.8244 & 4.8682 & 2.9673 & 3.7599 \\
\hline 5205320000 & 5.1434 & 5.4374 & 5.5008 & 7.1209 & 4.0031 & 1.0685 \\
\hline 5402330000 & 1.5137 & 1.5755 & 1.7106 & 1.8111 & 1.3777 & 1.0985 \\
\hline 5509320000 & 2.1755 & 1.9970 & 2.1718 & 2.6468 & 2.0848 & 1.6085 \\
\hline 5509510000 & 2.3016 & 2.3087 & 2.0324 & 1.7302 & 1.7909 & 1.7263 \\
\hline 5510110000 & 1.9626 & 1.8611 & 1.9373 & 1.9717 & 2.1045 & 2.1295 \\
\hline 5510300000 & 2.8061 & 2.7831 & 3.2807 & 1.9860 & 2.4294 & 1.2344 \\
\hline 5510900000 & 2.6529 & 4.2861 & 3.5929 & 0.6271 & 3.9076 & 3.7333 \\
\hline \multicolumn{7}{|l|}{15} \\
\hline 5208110000 & 3.6107 & 3.2627 & 4.6314 & 5.2176 & 4.5345 & 3.4320 \\
\hline 5208120000 & 2.2686 & 2.1642 & 3.1514 & 2.7187 & 3.7841 & 3.4323 \\
\hline 5209320000 & 3.1206 & 3.9508 & 3.7228 & 6.9757 & 3.2951 & 2.7021 \\
\hline 5209420000 & 3.6451 & 3.5771 & 4.5996 & 6.5133 & 3.2543 & 1.9006 \\
\hline 5211110000 & 3.5244 & 3.7298 & 3.4398 & 4.8403 & 4.8396 & 4.4260 \\
\hline 5407710000 & 2.9279 & 2.9564 & 3.7689 & 3.7965 & 4.0281 & 2.9527 \\
\hline 5512190000 & 4.7379 & 5.0500 & 2.3022 & 31.6180 & 1.9225 & 1.8951 \\
\hline 5513230000 & 2.5656 & 1.8668 & 3.9767 & 1.4065 & 2.4861 & 3.3668 \\
\hline 5514110000 & 3.7278 & 3.8328 & 5.8417 & 4.2669 & 5.7855 & 5.0883 \\
\hline 5516110000 & 3.1523 & 3.2790 & 4.2375 & 3.0671 & 4.4799 & 5.1184 \\
\hline 5516220000 & 4.8166 & 3.3460 & 1.1632 & 5.7705 & 2.4745 & 1.5235 \\
\hline 5516420000 & 4.9026 & 5.1350 & 6.6996 & 10.5380 & 7.8898 & 7.8883 \\
\hline 5516920000 & 4.9082 & 5.2680 & 8.3082 & 25.0694 & 5.6240 & 7.3763 \\
\hline \multicolumn{7}{|l|}{19} \\
\hline 4410110000 & 3.7810 & 1.3873 & 2.1106 & 5.4065 & 3.5016 & 1.9165 \\
\hline 4412320000 & 5.9651 & 5.1909 & 2.7135 & 220.4604 & 3.9454 & 3.9644 \\
\hline 4412940000 & 2.1252 & 2.1630 & 1.2908 & 2.2603 & 1.1702 & 1.1191 \\
\hline 4418720000 & 2.7784 & 2.1488 & 2.5706 & 2.9560 & 2.3800 & 2.2961 \\
\hline
\end{tabular}

Sumber: Data Ekspor Jawa Tengah dan Indonesia, diolah

Dari industri tekstil terdapat 13 komoditi zekspor yang mempunyai daya saing ekspor tinggi, yaitu kain tenunan dari kapas yang mengandung kapas 85 persen; kain tenunan dari kapas yang mengandung kapas kurang dari 85 persen dicampur terutama dengan serat buatan; kain tenunan dari benang filament sintetik; kain tenunan dari serat staple sintetik yang mengandung serat staple sintetik 85persen; kain tenunan dari serat staple sintetik yang mengandung serat staple sintetik kurang dari 85 persen dan dicampur dengan kapas dengan berat tidak lebih dari $170 \mathrm{~g} / \mathrm{m} 2$; kain tenunan dari serat staple sintetik yang mengandung serat staple sintetik kurang dari 85 persen dan dicampur dengan kapas dengan berat lebih dari $170 \mathrm{~g} / \mathrm{m} 2$; serta kain tenunan dari serat staple artifisial. 
Untuk industri kayu dan bahan bangunan dari kayu mencakup 4 jenis komoditi ekspor yang memiliki daya saing ekspor tinggi, yaitu papan partikel dan sejenisnya (misalnya, papan oriented strand dan papan wafer) atau kayu atau bahan mengandung lignin lainnya, diaglomerasi dengan resin atau dengan zat pengikat organik lainnya maupun tidak; kayu lapis, panel veneer dan kayu dilaminasi semacamnya; serta produk pertukangan dan bahan bangunan rumah dari kayu, termasuk panel kayu seluler, rakitan panel penutup lantai, atap sirap dan shake.

Gambar 5 memperlihatkan harga komoditi unggulan yang dihasilkan dan diekspor oleh industri pemintalan. Tampak bahwa harga dari komoditi tersebut berfluktuasi antara tahun 1997 sampai dengan 2015. Salah satu pemicu naik turunnya harga pada komoditi hasil industri pemintalan adalah karena bahan bakunya yang merupakan produk impor, sehingga goncangan yang terjadi baik di negara asal bahan baku maupun goncangan yang terjadi secara global akan sangat mempengaruhi hasil outputnya. Pada tahun 2011 secara bersama-sama harga dari semua komoditi hasil industri tekstil mengalami kenaikan yang disebabkan adanya kenaikan harga BBM.

Gambar 5. Harga Relatif Komoditi Hasil Industri Pemintalan Jawa Tengah Tahun 1997-2015

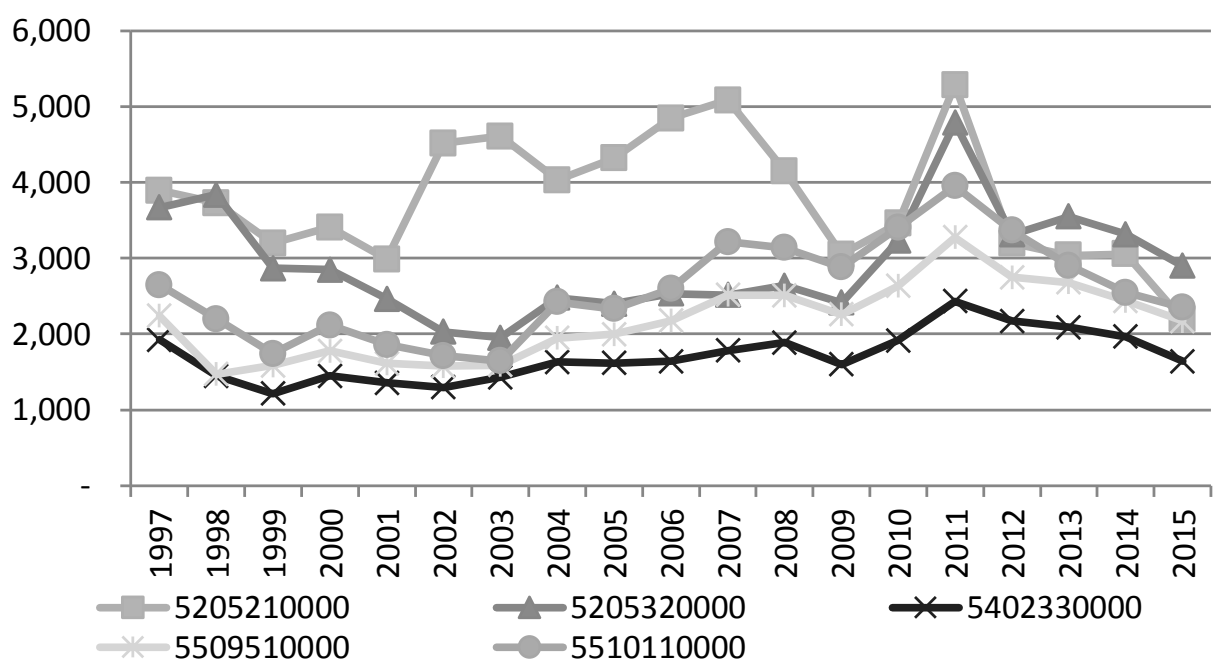

Sumber: Data Ekspor Jawa Tengah, diolah

Gambar 6. Harga RelatifKomoditi Hasil Industri Tekstil Jawa Tengah Tahun 1997-2015

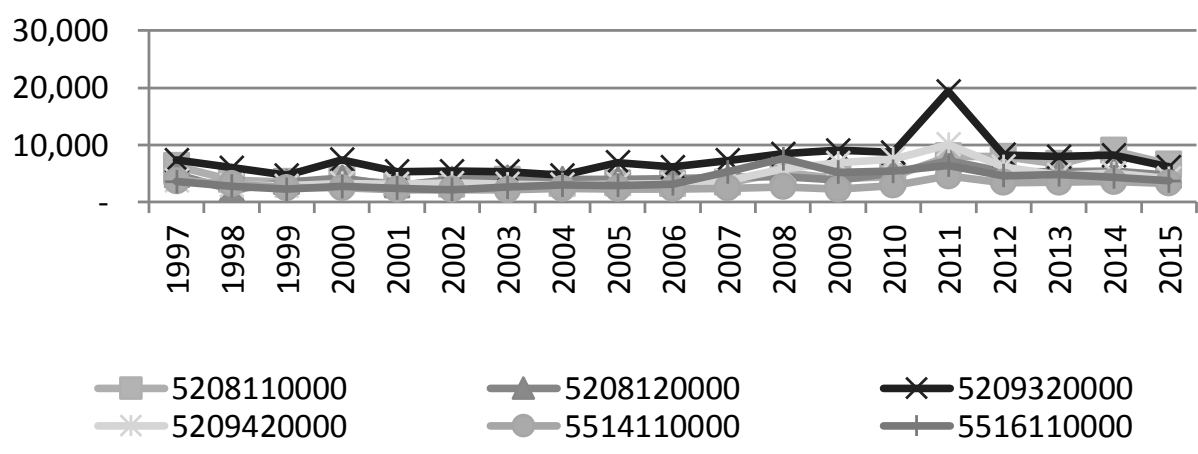

Sumber: Data Ekspor Jawa Tengah, diolah 
Harga dari komoditi-komoditi tersebut akan mengalami kenaikan saat terjadi goncangan ekonomi, namun akan kembali turun ke harga keseimbangan. Namun untuk komoditi 5205210000 (Benang kapas selain benang jahit- mengandung kapas $85 \%$ atau lebih menurut beratnya, ukuran 714,29 desiteks atau lebih tidak melebihi nomormetrik 14 - tidak disiapkan untuk penjualan eceran) belum mencapai harga keseimbangan, dimana harganya masih sangat fluktuatif.

Begitu pula yang terjadi pada komoditi unggulan hasil industri tekstil, harganya mengalami fluktuasi meskipun tidak terlalu ekstrim. Hal ini dikarenakan untuk bahan baku industri tekstil tidak sepenuhnya mengandalkan impor, sehingga lebih kuat dan tidak terpengaruh oleh goncangan yang terjadi di perekonomian global (lihat Gambar 6).

Naiknya harga bahan bakar minyak (BBM) pada tahun 2011 menjadi salah satu penyebab meningkatnya harga komoditi ekspor pada tahun tersebut. Pengeluaran untuk BBM mempunyai andil yang relatif besar pada biaya produksi suatu industri sehingga kenaikan harga BBM akan berpengaruh besar pada aktifitas industri, yang pada akhirnya berimbas pada naiknya harga penjualan.

Komoditi unggulan pada industri kayu dan bahan bangunan dari kayu ternyata baru diperdagangkan ke negara lain secara konsiten mulai tahun 2007. Bahkan untuk komoditi 4412320000 (Kayu lapis, panel veneer dan kayu dilaminasi, paling tidak dengan satu lapisan luar bukan darikayu pohon konifera) baru diperdagangkan ke negara lain mulai tahun 2009. Meskipun begitu, untuk tiga (3) jenis komoditi unggulan industri kayu dan bahan bangunan dari kayu tampak sudah berada pada harga keseimbangan dengan kecenderungan meningkat setiap tahunnya. Hanya pada komoditi 4412320000(Kayu lapis, panel veneer dan kayu dilaminasi, paling tidak dengan satu lapisan luar bukan dari kayu pohon konifera) yang masih mengalami fluktuasi harga dan belum mencapai harga keseimbangan (lihat Gambar 7).

Gambar 7. Harga Relatif Komoditi Hasil Industri Kayu \& Bahan Bangunan dari Kayu Jawa Tengah Tahun 1997-2015

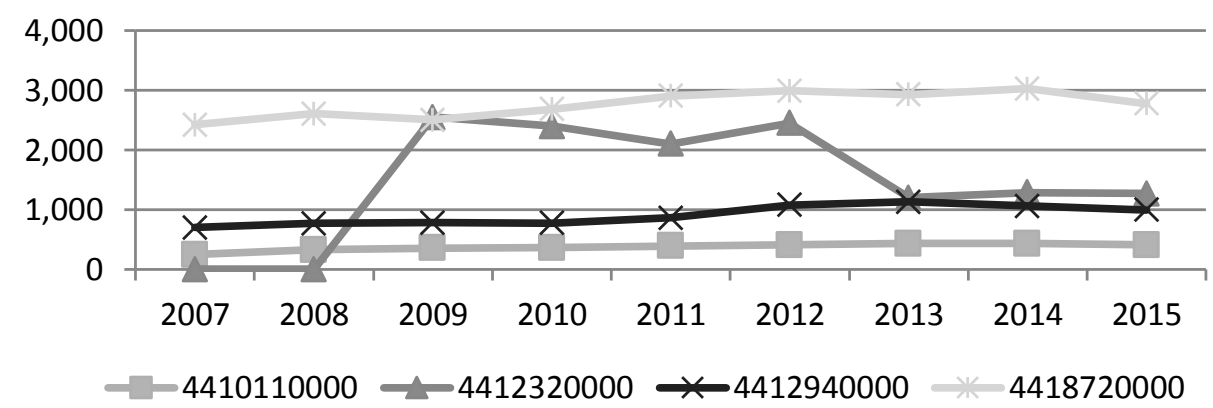

Sumber: Data Ekspor Jawa Tengah, diolah

\section{Strategi Kebijakan}

Pada tingkat makro, peningkatan daya saing sektor industri secara berkelanjutan membutuhkan landasan ekonomi yang kuat terutama melalui upaya menjaga stabilitas ekonomi makro serta perwujudan iklim usaha dan investasi yang sehat. Kondisi tersebut akan memfasilitasi terciptanya inovasi dan peningkatan produktivitas serta pemanfaatan ilmu pengetahuan dan teknologi di berbagai lapisan perusahaan. Dalam tataran mikro, meminjam identifikasi United Nation Industry Development Organization (UNIDO), terdapat 4 (empat) faktor utama yang perlu diperhatikan dalam meningkatkan daya saing sektor industri yaitu: (a) kemampuan (ketrampilan) SDM, (b) penguasaan dan penerapan teknologi, (c) aliran masuk FDI sebagai potensi sumber alih teknologi dan perluasan pasar ekspor, dan (d) kapasitas infrastruktur (termasuk infrastruktur bagi pengembangan teknologi).

Arah pengembangan sektor industri manufaktur ke depan adalah mendorong terwujudnya peningkatan utilitasi kapasitas; memperluas basis usaha dengan penyederhanaan prosedur perijinan dan penyelenggaraan usaha untuk peningkatan peran 
industri kecil dan menengah; meningkatkan iklim persaingan yang sehat dan berkeadilan; memperluas penerapan standarisasi produk industri; dan mendorong perkuatan struktur industri pada subsektor yang memiliki potensi keuntungan kompetitif ke depan.

Apabila mekanisme pasar tidak dapat berlangsung efisien, langkah-langkah intervensi strategis diselenggarakan secara fungsional dalam kepentingan menjaga kesinambungan pembangunan sekaligus perkuatan struktur industri. Hal tersebut terutama terkait dengan pengembangan teknologi dan keterampilan tenaga kerja industri, layanan informasi pasar baik di dalam maupun luar negeri, serta sarana dan prasarana umum pengendalian mutu dan pengembangan produk.

Dengan semakin ketatnya persaingan global dan semakin pesat dan spesifiknya perkembangan teknologi, kualitas kebijakan industri dituntut lebih baik dan lebih tepat sasaran. Prioritas pengembangan sektor industri haruslah ditetapkan pada subsektor industri pengolahan yang memenuhi satu atau lebih kriteria sebagai berikut: (1) menyerap banyak tenaga kerja; (2) memenuhi kebutuhan dasar dalam negeri; (3) memiliki potensi pengembangan ekspor; dan (4) mengolah sumberalam dalam negeri.

Berdasarkan hasil pengolahan data dinyatakan bahwa terdapat 3 sektor industri unggulan di Jawa Tengah yang mempunyai daya saing ekspor tinggi, yaitu industri pemintalan, industri tekstil, dan industri kayu dan bahan bangunan dari kayu. Ketiga industri tersebut haruslah mendapat perhatian khusus dari pemerintah, karena keberlangsungan industriindustri tersebut memberikan efek positif bagi perekonomian Jawa Tengah. Kebijakan yang akan diterapkan dapat dilihat dari nilai IDP dan IDK yang dimiliki oleh industri-industri tersebut.

Industri pemintalan memiliki IDP = 1,1996302 dan IDK $=1,0736756$. Artinya kemampuan industri pemintalan dalam mendorong sektor hilirnya untuk tumbuh lebih besar daripada kemampuannya dalam menarik sektor hulu untuk berkembang (IDP $>$ IDK). Sektor hilir dari industri pemintalan adalah industri tekstil, industri tekstil jadi dan tekstil lainnya, serta industri pakaian jadi, maka strategi utama yang dapat dikembangkan oleh pemerintah adalah menyediakan kemudahan dalam pemasaran produknya, baik dengan memperkuat pasar domestik maupun mempermudah akses ke pasar internasional. Atau dengan cara penerapan standardisasi produk industripemintalan maupun industri tekstil sebagai faktor penguat daya saing produk nasional serta memfasilitasi aliran masukforeign direct investment (FDI) sebagai potensi sumber alih teknologi dan perluasan pasar ekspor.

Industri berikutnya yang merupakan unggulan di Jawa Tengah adalah salah satu industri strategis dan memiliki nilai ekonomi maupun penciptaan tenaga kerja massal, yaitu industri tekstil. Industri tekstil memiliki IDP $=1,1678345$ dan IDK=1,2283157, hal ini mengindikasikan bahwa industri tekstil mempunyai kemampuan menarik sektor hulu yang merupakan penyuplai bahan baku untuk tumbuh lebih tinggi sehingga berkontribusi lebih besar dalam perekonomian (IDK >IDP). Industri hulu dari industri tekstil adalah industri pemintalan, yang merupakan sektor industri unggulan juga di Jawa Tengah. Padahal seperti yang kita tahu selama ini sebagian besar bahan baku industri tekstil masih mengandalkan produk impor. Kondisi merupakan tantangan dan peluang yang sangat menjanjikan jika Jawa Tengah mulai memikirkan pembangunan industri bahan bakutekstil.Apalagi, bahan bakutekstil berupa rayon yang diolah dari pulp yang dapat dihasilkan dari hutan tanaman industri eucalyptusyang ada di Indonesia. Sehingga sudah saatnya pemerintah daerah berusaha untuk untuk mengurangi ketergantungan dari produk luar negeri dan melakukan kebijakan subsitusi impor dengan cara mendorong pembangunan industri bahan baku industri dalam negeri, khususnya Jawa Tengah.

Industri ketiga yang merupakan unggulan Jawa Tengah adalah industri kayu dan bahan bangunan dari kayu.Industri ini memiliki IDP $=1,2272487$ dan $\mathrm{IDK}=1,3524840$, yang artinya industri ini mempunyai daya tarik terhadap sektor hulunya yang lebih kuat daripada daya dorongnya terhadap sektor hilir (IDP<IDK). Sektor hulu dari industri kayu dan bahan bangunan dari kayu adalah sektor kehutanan. Kebijakan yang dapat dilakukan oleh pemerintah daerah dalam usaha peningkatan kualitas dan volume produksi industrikayu dan bahan bangunan dari kayu adalah dengan cara meningkatkan tata kelola kehutanan (good forest governance) serta meningkatkan produksi dan 
produktivitas sumber daya hutan. Karena seperti kita ketahui bahwa bahan bakuindustrikayu dan bahan bangunan dari kayu adalah produk hasil hutan, baik hutan Negara maupun hutan rakyat.

Peningkatan tata kelola kehutanan dilakukan dengan cara membentuk Kesatuan Pengelolaan Hutan Produksi (KPHP) dan operasionalisasinya, menerapkan prinsip pengelolaan hutan lestari, memberikan jaminan legalitas hasil hutan kayu dan produk kayu, meningkatkan kompetensi sumber daya manusia untuk mendukung operasionalisasi $\mathrm{KPH}$, serta mengembangkan forest based cluster industry.Sedangkan untuk meningkatkan produksi dan produktivitas sumber daya hutan dapat dilakukan dengan penerapan ilmu pengetahuan dan teknologi untuk meningkatkan nilai tambah produk kayu serta diversifikasi produk serta meningkatkan keterlibatan masyarakat sebagai mitra usaha.

\section{DAFTAR PUSTAKA}

Abdullah, Muhammad, et al. 2015. Where Pakistan Stands Among Top Rice Exporting Countries, an Analysis of Competitiveness. Journal of Northeast Agricultural University, Volume 22, Pages 80-86.

Alisjahbana, Armida S, dkk. 2008. Profil dan Pemetaan Daya Saing Ekonomi Daerah Kabupaten/Kota di Indonesia. Rajawali Pers. Jakarta

Alisjahbana, Armida S. 2014. Arah Kebijakan dan Strategi Percepatan Pengembangan Kawasan Timur Indonesia. Kementerian Perencanaan Pembangunan Nasional/Badan Perencanaan Pembangunan Nasional. Manado.

Amir. 2004. Korespondensi Bisnis Ekspor Impor. PPM. Jakarta.

Arief D danYundy H. 2010. Model-Model Kuantitatif Untuk Perencanaan Pembangunan Ekonomi Daerah: Konsep dan Aplikasi. CetakanPertama. PT Penerbit IPB Press. Bogor.

Arisman. 2002. Analisis Kebijakan: DayaSaing CPO Indonesia. Jurnal Universitas
Paramadina Vol.2 No.1, September 2002; hal: $75-90$

Badan Pusat Statistik. 1999. Kerangka Teori dan Analisis Tabel Input-Output. Cetakan Kedua. BPS. Jakarta. .2001.Teknik Penyusunan Tabel InputOutput. BPS. Jakarta. 2015. PDRB Provinsi - Provinsi di Indonesia menurut Lapangan Usaha 2008-2014. BPS. Jakarta.

Badan Pusat Statistik Provinsi Jawa Tengah. 2009. Tabel Input Output Jawa Tengah Tahun 2013. BPS. Semarang.

2015. Statistik Ekspor Jawa Tengah 2014. BPS Provinsi Jawa Tengah. Semarang.

2015. Statistik Industri Manufaktur Besar Sedang Jawa Tengah 2014. BPS Provinsi Jawa Tengah. Semarang.

Badan Kebijakan Fiskal. 2011.PublikasiKebijakan:

DayaSaingProduk Indonesia, India, dan ASEAN DalamKerangka ASEAN-India Free Trade Area (AIFTA) Dengan Menggunakan Pendekatan Revealed Comparative Advantage (RCA).Kajian Ekonomidan Keuangan.Jakarta.

Budiono, Armida A, dkk. 2002. Daya Saing Daerah: Konsep dan Pengukurannya di Indonesia. Badan Penerbit FE-UGM. Yogyakarta.

Bea dan Cukai. 2012. Buku Tarif Bea Masuk Indonesia.

Bustami, BR dan Paidi H. 2013. Analisis Daya Saing Produk Ekspor Provinsi Sumatera Utara. Jurnal Ekonomi dan Keuangan, Vol. 1, No. 2, Januari 2013.

Hadi, Prayogo U. \& Budi Wiryono. 2015. Dampak Kebijakan Proteksi Terhadap Ekonomi Beras di Indonesia. Jurnal Agro Ekonomi, Volume: 23, No: 2. Oktober 2015, pg: 159-175.

Halwani, Hendra R. 2005. Ekonomi Internasional dan Globalisasi Ekonomi. Edisi Kedua. Ghalia Indonesia. Bogor.

Ibrahim, dkk. 2010. Dampak Pelaksanaan ACFTA Terhadap Perdagangan Internasional Indonesia. Buletin Ekonomi Moneter dan Perbankan, Juli 2010. 
IMD. 2014. World Competitiveness Yearbook 2014. IMD World Competitiveness Center. Switzerland

Irham dan Yogi. 2003. Ekspor di Indonesia. Cetakan Pertama. Pustaka Binaman Pressindo. Jakarta.

Jhingan, M.L. 2000. Ekonomi Pembangunan dan Perencanaan. PT Raja Grafindo Perkasa. Jakarta.

Kesumawijaya, I.W.W. Analisis Keseimbangan Spasial dan Simultan Dalam Sistem Ekonomi (Suatu Kajian Optimasi Dinamik). Makalah.

Kula, Mehmet. 2008. Supply-Use and Input Output Tables, Backwad and Forward Linkages of The Turkish Economy. The $16^{\text {th }}$ Inforum World Conference in Northern Cyprus: 1-5 September 2008.

Kuncoro, Mudrajat. 2009. Ekonomika Indonesia; Dinamika Lingkungan Bisnis di Tengah Krisis Global. UPP STIM YKPN. Yogyakarta.

Kuraisin, Vivin. 2006. Analisis Daya Saing dan Dampak Kebijakan Pemerintah terhadap Komoditi Susu Sapi. Skripsi. Departemen Ilmu-Ilmu Sosial Ekonomi. Fakultas Pertanian. Institut Pertanian Bogor. Bogor.

Kusdiana, D \& Candra W. 2007. Analisis Daya Saing Ekspor Sektor Unggulan di Jawa Barat. Jurnal Trikonomika Fakultas Ekonomi Pasundan Vol. 6, No.1. Bandung.

Krugman, Paul R, \& Obstfeld M. 2004. Ekonomi Internasional, Teori dan Kebijakan. Edisi Kelima, Jilid I. PT Indeks Kelompok Gramedia. Jakarta.

Luo, Jianxi, et al. 2014. Technology Based Design and Sustainable Economic Growth Technovation, Volume 34, Pages 663-677.

Mankiw, N Gregory. 2006. Pengantar Ekonomi Makro. Edisi Ketiga. Salemba Empat. Jakarta.

Mawardi, I. 1997. Daya Saing Indonesia Timur dan Pengembangan Ekonomi Terpadu. Lembaga Penelitian, Pendidikan dan Penerangan Ekonomi dan Sosial. Jakarta.

Moyi, Elliud\& Peter Kimuyu. 1999. Revealed Comparative Advantage and Export Propensity in Kenya. Institute of Policy Analysis and Research.
MS, Amir. 2003. Ekspor ImporTeori dan Penerapannya. PPM. Jakarta.

Perlines, Felipe Hernandez, et al. 2016. The Mediating Role of Competitive Strategy in International Entrepreneurial Orientation. Journal of Business Research, Volume 69, Pages 456-466.

Porter, M. 1990. Competitive Advantage of Nations. New York: Free Press. Macmillan.

Purnomo, Didit \& Devi Istiqomah. 2008. Analisis Peranan Sektor Industri Terhadap Perekonomian Jawa Tengah Tahun 2000 dan Tahun 20004 (Analisis Input Output). Jurnal Ekonomi Pembangunan Vol. 9, No. 2

Rachbini, Didik J. 2001. Pembangunan Ekonomi dan Sumber Daya Manusia. Gramedia Widiasarana Indonesia. Jakarta.

Ropingi \& Dany A. 2002. Peran Sektor Pertanian dalam Pengembangan Perekonomian Wilayah Provinsi Jawa Tengah (Pendekatan Analisis Input Output).

Salvatore, D. 2014. Ekonomi Internasional. Edisi 9-Buku 1. Salemba Empat. Jakarta.

Salvatore, D. 2014. Ekonomi Internasional. Edisi 9-Buku 2. Salemba Empat. Jakarta.

Salvatore, D \& Diulio, Eugene. 2004. PrinsipPrinsip Ekonomi. Erlangga. Jakarta.

Sanusi, Bachrawi. 2004. Pengantar Ekonomi Pembangunan. PT Rineka Cipta. Jakarta.

Samuelson, P.A. \& W.D. Nordhaus. 1998. Ekonomi. Edisi 12:Jilid I. Erlangga. Jakarta.

Samuelson, P.A. \& W.D. Nordhaus. 2004. Ilmu Makro Ekonomi. Edisi 17. Media Global Edukasi. Jakarta.

Sjafrizal. 2008. Ekonomi Regional, Teori dan Aplikasi. Boduose Media. PadangSumatera Barat.

Syafaat, N \& Supena F. 2000. Analisis Dampak Krisis Ekonomi Terhadap Kesempatan Kerja dan Identifikasi Komoditas Andalan Sektor Pertanian di Wilayah Sulawesi: Pendekatan Input Output. Ekonomi dan Keuangan Indonesia. Vol: XLVIII. No: 4.

Saptana. 2005. Keunggulan KomparatifKompetitif dan Strategi Kemitraan. Pusat Penelitian dan Pengembangan Sosial Ekonomi Pertanian. Badan 
Wiwit Santi Wahyuningsih/ Economics Development Analysis Journal 6 (2) (2017)

Litbang Pertanian: Departemen Pertanian RI.

Sukirno, S. 2006. Ekonomi Pembangunan. Kencana Grup. Jakarta.

Sukirno, S. 2008. Mikro Ekonomi Teori Pengantar. PT Raja Grafindo Persada. Jakarta.

Suprihatini, R. 2005. Daya Saing Ekspor Teh Indonesia di Pasar The Dunia. Jurnal Agro Ekonomi, Vol.23 No.1, Mei 2005; hal:1-29.

Tambunan, Tulus. 2001. Perekonomian Indonesia. Ghalia Indonesia. Jakarta.

Tambunan, Tulus. 2006. Entrepreneurship Development: SMES In Indonesia. Journal of Development Entrepreneurship Vol. 12, No. 1 (2007) 95-118. Jakarta.

Tarigan, Robinson. 2005. Ekonomi Regional Teori dan Aplikasi. Edisi Revisi. Bumi Aksara. Jakarta.

Tarigan, Robinson. 2006. Perencanaan Pembangunan Wilayah. Bumi Aksara. Jakarta.

Todaro, M.P. 2006. Pembangunan Ekonomi di Dunia Ketiga. Edisi Kedelapan. Erlangga. Jakarta.

Tumenggung, S. 1996. Gagasan dan Kebijaksanan Pembangunan Ekonomi Terpadu (Kawasan Timur Indonesia). Direktorat Bina Tata Perkotaan dan Pedesaan Dirjen Cipta Karya Departemen PU. Jakarta.

Utami, Naniek dkk. 2012. Faktor-faktor yang Mempengaruhi Peningkatan Daya Saing Klaster Mebel di Kabupaten Jepara. Jurnal Teknik Industri, Vol.3 No.1, Februari 2012; hal:22-30.

Utomo, Y. Priadi. 2000. Ekspor Mendorong Pertumbuhan Ekonomi atau Pertumbuhan Mendorong Ekspor. Jurnal Management. UII.

Widyasanti, A.A. 2010. Perdagangan Bebas Regional dan Daya Saing Ekspor: Kasus Indonesia. Buletin Ekonomi Moneter dan Perbankan. Juli 2010.

Widodo, Tri. 2006. Perencanaan Pembangunan: Aplikasi Komputer. UPP STIM YKPN. Yogyakarta.

World Economic Forum. 2015. The Global Competitiveness Report 2015-2016. World Economic Forum. Geneva.

Woroutami, A.D. 2010.Analisis Sektor-Sektor Unggulan Dallam Menggerakkan Sektor
Riil. Kajian Ekonomi dan Keuangan Volume 14 No. 1, Jakarta. 